
3 Research Square
Preprints are preliminary reports that have not undergone peer review.
They should not be considered conclusive, used to inform clinical practice, or referenced by the media as validated information.

\title{
The Strategy and Efficacy of Prophylaxis Against Hepatitis B Virus Recurrence After Liver Transplantation in the Era of High Potent Nucleos(t)ide Analogues: A Meta-Analysis
}

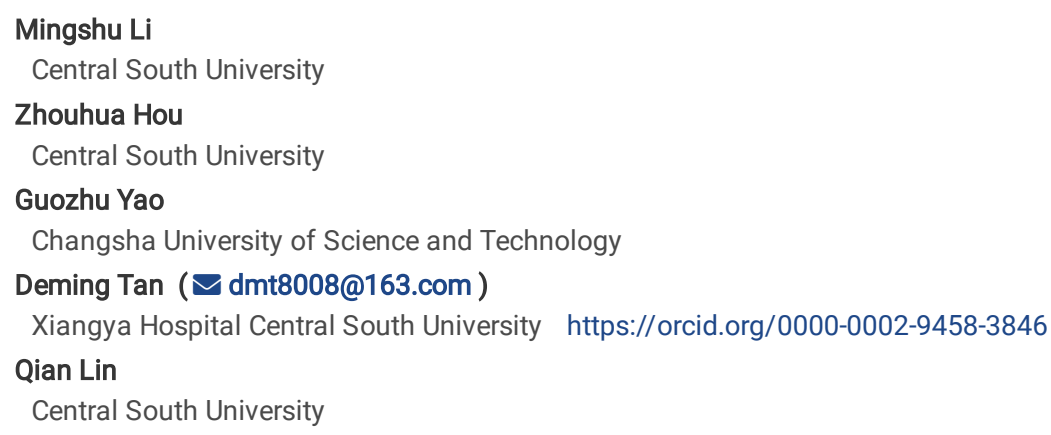




\section{Abstract}

Background: High potent nucleos(t)ide analogues (HP NAs) with or without hepatitis B immunoglobulin (HBIG) is the standard prophylactic therapy for avoiding the HBV recurrence after liver transplantation (LT). While the clinical impact of HP NAs-based prophylaxis has not been well documented, the optimal treatment strategy is currently debated. This meta-analysis aims to evaluate clinical outcome of LT recipients under HP NAs-based regimens and investigate different prophylaxis schemes.

Methods: We followed PRISMA statement to conduct this study. Two reviewers independently searched relevant literature via PubMed, EMBAES, MED LINE, Web of Science, and Google Scholar. Studies were included if they observed HBV recurrence under HP NAs-based regimens in patients who received HBVrelated LT. Primary and secondary outcome were HBV recurrence, HCC recurrence, all-cause and HBV-recurrence related mortality. Incidence with $95 \%$ confidence intervals was aggregated and assess by fixed effect model/random effect model. Subgroup analysis was applied to examine the impact of different treatment strategies.

Results: 26 studies ( $n=2374)$ were included, with a pooled HBV recurrence rate of $0.92 \%(95 \% \mathrm{Cl} 0.47 \%-1.48 \%)$. Studies with and without HBV viremia or HDV superinfected patients demonstrated comparable HBV recurrence $(p=0.25, p=0.69)$. Recurrence rate under indefinite combination of HP NAs and HBIG was lower than that under HP NAs monotherapy $(\mathrm{p}=0.0003)$, and similar to that under NAs plus finite course of HBIG $(\mathrm{p}=0.53)$. Pooled HCC recurrence rate was $5.34 \%$ (95\% Cl 0.78\%-12.48\%). HBV-recurrence related mortality and all-cause mortality were $0.17 \%(95 \% \mathrm{Cl} 0.00 \%-1.51 \%)$ and $7.29 \%(95 \% \mathrm{Cl} 4.42 \%-10.71 \%)$ respectively.

Conclusion: Our study suggests HP NAs-based regimens provide satisfactory HBV antiviral prophylaxis and improved long-term outcome for LT recipients. Finite combination of HP NAs and HBIG is an alternative to lifelong dual therapy.

\section{Background}

For patients with chronic hepatitis B virus (HBV) infection, the prognosis after liver transplantation (LT) has been improved markedly, largely attributable to prophylaxis against HBV recurrence ${ }^{1-3}$. The first milestone of preventive therapy was long-term hepatitis B immune globulin (HBIG), which tremendously decreased the risk of graft infection (from $75 \%$ to $33 \%$ ) and increased 3-year survival (from $54 \%$ to $83 \%$ ) ${ }^{4,5}$. Despite of the advances, HBIG monotherapy was far from satisfactory. The efficacy was compromised among patients with high risk of HBV reactivation or those developed immune escape ${ }^{6-8}$. Other problems such as supply limitation and high cost were difficult to ignore ${ }^{9}$. The second breakthrough for HBV recurrence prophylaxis was antiviral agents. Lamivudine (LAM) and/or adefovir (ADV) proved synergistic activity with HBIG by further lowering the HBV recurrence rate to less than $10 \%{ }^{10-12}$. Nevertheless, the emerging issues such as YMDD mutants and renal impairment were major obstacles to long-term application of these low potent nucleos(t)ide analogues (LP NAs) ${ }^{13-16}$.

A new era came with the development of high potent and high genetic barrier nucleos(t)ide analogues (HP NAs, i.e. entecavir, tenofovir disoproxil fumarate, tenofovir alafenamide). As the safety and efficacy being proved in registrational and real-world studies, HP NAs have been substituted for LP NAS as the preferred antiviral prophylaxis ${ }^{17-21}$. Although there have been numerous clinical studies relevant to this topic, the only systematic review focusing on HP NAsbased prophylaxis was issued in $2013^{22}$. In that review, Cholongitas E and Papatheodoridis GV included 519 patients treated by combination of HP NAs and $\mathrm{HBIG}$, and they found HBV recurrence incidence under indefinite combination of HP NAs and HBIG was 1.0\%, significantly lower than that under LAM plus HBIG. Since HP NAs-based regimens have become standard care for LT recipients in recent years ${ }^{19-21}$, the critical issues are not their rationale of usage anymore, but rather their clinical outcomes and treatment strategy. The HBV reinfection and recipients' mortality under HP NAs-based therapies is not clear. In terms of treatment strategy, there are still many questions need to be answer, for example what the risk factors of HBV recurrence for HP NAs-based therapies are, whether HP NAs monoprophylaxis is equally effective as combination of HP NAs and HBIG. Therefore, we conducted this meta-analysis to probe these two issues and hope to provide evidence for clinical practice.

\section{Methods}

\subsection{Literature search strategy}

We followed PRISMA (Preferred reporting items for systematic review and meta-analyses) statement to conduct this study (23). A comprehensive literature search was performed via PubMed, EMBAES, MEDLINE, Web of Science, and Google Scholar under the terms of "liver transplantation", "HBV recurrence", "entecavir" and "tenofovir". For example, the search algorithm in PubMed was: ((liver transplantation) AND ((HBV recurrence) OR HBV reactivation)) AND ((entecavir) OR tenofovir). Abstract books from the major international transplantation conferences and hepatology meetings were also reviewed. Literature search was last updated on February 2020.

\subsection{Study selection and data extraction}

Studies which published in English and fulfilled all of the following criteria were included: 1. Subject: adult patients received HBV-related LT. 2. Intervention: Entecavir or tenofovir disoproxil fumarate or tenofovir alafenamide (with or without HBIG). 3. Study design: RCT or observational cohort studies. We excluded the studies if they met any following criterion: 1. The number of patients who used HP NAs was less than 10. 2. Median/mean follow-up period was less than 12 months, since we expect the episode of HBV recurrence may not be captured during short period of follow-up. 3. HBV recurrence rate was not mentioned for 
HP NAs group. 4. Patients were exposed to LP NAs after LT. Two authors (Li MS, Hou ZH) conducted the literature search and screen independently, any disagreement was resolved by consensus or consulting to corresponding author.

\subsection{Data Extraction}

Data from manuscript and abstract were extracted manually (Li MS), in aspect of patient characteristics, therapeutic regimen and clinical outcome. To describe patient characteristics, the proportion of patients with pre-LT HCC, quantifiable HBV DNA and HDV coinfection was pulled. Drugs, treatment duration and administrative route were recorded. In terms of clinical outcomes, events of HBV reactivation, HCC recurrence, HBV recurrence-related mortality and allcause mortality were calculated. Parameters related to renal function were also extracted to review the impact of HP NAs on renal safety.

\subsection{Assessment of quality (risk of bias)}

Newcastle-Ottawa scale (NOS) and Cochrane Collaboration's tool for assessing risk of bias (RoB) were used to evaluate the study quality/risk of bias for observational studies and RCT 24, 25. In the NOS system, quality of observational study was rated as high, moderate or low based on total score i.e. score 7-9 indicated high study quality, 4-6 fair quality, and 0-3 low quality. According to RoB, the risk of bias of each RCT was graded as high, unclear or low by 6 domains.

\subsection{Data analysis}

The primary study outcome was HBV recurrence, which was defined by original studies or as reappearance of HBsAg and/or HBV DNA if there was no definition in original studies. The secondary outcome included HCC recurrence, HBV recurrence-related mortality and all-cause mortality. Heterogeneity across studies was assessed by l-square index, which indicated substantial heterogeneity with a value over $50 \%$ (26). Random effect model was applied in case of significant heterogeneity, and fixed effect model was used in the absence or minor heterogeneity (27). Subgroup analysis was conduct by risk factors, HP NAs, combination approaches and administration of HBIG. We made sensitivity analysis to examine the robustness of primary finding. Meta-analysis was conducted with the R software program (version 3.6.2) and the R-package meta.

\section{Results}

\subsection{Studies and patient characteristics}

A total of 419 citations were identified by initial search, 348 duplicated or irrelevant records were later removed. According to the inclusion/exclusion criteria, 45 literature was further excluded, and final 26 studies $(n=2374)$ were included for our analysis (Figure 1).

The study and patient characteristics were summarized in Table 1. 24 observational studies and 2 RCT were included. 21 of them were presented in manuscript, and 5 in conference abstract. 18 studies were conducted in Asia, 3 in Europe, 3 in North America, 1 in Australia, and 1 across continents. 15 studies enrolled patients with HBV viremia and 5 included patients with HDV superinfection. HCC was a major indication for LT, responsible for $13.6 \%$ to $80 \%$ of the surgical cases. Considerable follow-up period was ensured across the studies, with $84.6 \%(22 / 26)$ over 24 months and $30.7 \%$ (8/26) over 48 months 
Table 1

Identified studies for systematic review and meta-analysis

\begin{tabular}{|c|c|c|c|c|c|c|c|c|c|c|c|}
\hline First Author & Year & $\begin{array}{l}\text { Study } \\
\text { design }\end{array}$ & $\begin{array}{l}\text { NOS } \\
\text { score/ } \\
\text { RoB }\end{array}$ & $\begin{array}{l}\text { Pre- } \\
\text { transplant } \\
\text { HBV DNA } \\
\text { positivity } \\
(\%)\end{array}$ & $\begin{array}{l}\text { Pre-transplant } \\
\text { HDV } \\
\text { superinfection } \\
(\%)\end{array}$ & $\begin{array}{l}\text { HCC } \\
\text { before } \\
\text { LT (\%) }\end{array}$ & $\begin{array}{l}\text { HP NAs-based } \\
\text { regimen }\end{array}$ & $\begin{array}{l}\text { Median/mean } \\
\text { Follow-up } \\
\text { period } \\
\text { (month) }\end{array}$ & $\begin{array}{l}\text { Definition of } \\
\text { HBV } \\
\text { recurrence }\end{array}$ & $\begin{array}{l}\text { HBV } \\
\text { recurrence }\end{array}$ & $\begin{array}{l}\mathrm{HE} \\
\text { rec } \\
\text { rel } \\
\mathrm{mc}\end{array}$ \\
\hline Xi ZF ${ }^{[28]}$ & 2009 & $\mathrm{RC}$ & 6 & 60.0 & NA & 41.6 & $\mathrm{ETV}+\mathrm{HBIG}$ & 34 & $\begin{array}{l}\text { reappearance } \\
\text { of both } \\
\text { HBsAg and } \\
\text { HBV DNA }\end{array}$ & $0 / 30$ & $\mathrm{~N} f$ \\
\hline Cai CJ[29] & 2012 & $\mathrm{RC}$ & 6 & $\begin{array}{l}\text { Mean } \\
\text { level } \\
8.74 \times 10^{6} \\
\mathrm{cp} / \mathrm{ml}\end{array}$ & NA & 29.9 & ETV+HBIG & 41.2 & $\begin{array}{l}\text { reappearance } \\
\text { of HBsAg }\end{array}$ & $0 / 63$ & $\mathrm{~N} f$ \\
\hline $\begin{array}{l}\text { Teperman } \\
\text { LW }^{[30]}\end{array}$ & 2013 & $\mathrm{RCT}$ & $\begin{array}{l}\text { Unclear } \\
\text { risk of } \\
\text { bias }\end{array}$ & NA & 0 & NA & $\mathrm{FTC} / \mathrm{TDF} \pm \mathrm{HBIG}$ & 18 & HBV viremia & $0 / 37$ & $0 /$ \\
\hline Yi NJ[31] & 2013 & PC & 5 & NA & 0 & 72.4 & $\begin{array}{l}\text { Sequential ETV } \\
\text { following } \\
\text { HBIG+ETV }\end{array}$ & 32.6 & $\begin{array}{l}\text { reappearance } \\
\text { of } \mathrm{HBsAg}\end{array}$ & $1 / 29$ & $0 /$ \\
\hline Kim YK ${ }^{[32]}$ & 2013 & $\mathrm{RC}$ & 4 & 26.0 & 0.6 & NA & ETV+HBIG & 28 & $\begin{array}{l}\text { reappearance } \\
\text { of } \mathrm{HBsAg}\end{array}$ & $5 / 154$ & $0 /$ \\
\hline Perrillo $\mathrm{R}^{[33]}$ & 2013 & PC & 6 & 0 & NA & 36.9 & ETV+HBIG & 18 & HBV viremia & $0 / 61$ & $\mathrm{~N} /$ \\
\hline Ueda $Y^{[34]}$ & 2013 & $\mathrm{RC}$ & 5 & 46.0 & NA & 53.9 & $\mathrm{ETV+HBIG}$ & 25.1 & $\begin{array}{l}\text { reappearance } \\
\text { of HBsAg } \\
\text { and/or HBV } \\
\text { DNA }\end{array}$ & $0 / 26$ & $0 /:$ \\
\hline Elsiesy $\mathrm{H}^{[35]}$ & 2013 & $\mathrm{RC}$ & 4 & 40.0 & NA & NA & $\begin{array}{l}\text { ETV+HBIG, } \\
\text { TDF+HBIG }\end{array}$ & 32 & $\begin{array}{l}\text { reappearance } \\
\text { of HBsAg or } \\
\text { HBV DNA }\end{array}$ & $0 / 15$ & $\mathrm{~N} f$ \\
\hline $\begin{array}{l}\text { Cholongitas } \\
E^{[36]}\end{array}$ & 2014 & PC & 5 & 0 & 28.0 & 50.0 & $\begin{array}{l}\text { Sequential ETV, } \\
\text { TDF following } \\
\text { HBIG+ETV or } \\
\text { HBIG+TDF }\end{array}$ & 18 & $\begin{array}{l}\text { reappearance } \\
\text { of HBsAg } \\
\text { and/or HBV } \\
\text { DNA }\end{array}$ & $0 / 28$ & $0 /:$ \\
\hline $\mathrm{Na} \mathrm{GH}{ }^{[37]}$ & 2014 & $\mathrm{RC}$ & 5 & 74.9 & NA & 54.0 & ETV+HBIG & 49 & $\begin{array}{l}\text { reappearance } \\
\text { of } \mathrm{HBsAg}\end{array}$ & $4 / 262$ & $\mathrm{~N} f$ \\
\hline $\mathrm{Hu} \mathrm{TH}^{[38]}$ & 2014 & PC & 6 & NA & NA & NA & ETV+HBIG & 36 & $\begin{array}{l}\text { reappearance } \\
\text { of } \mathrm{HBsAg}\end{array}$ & $2 / 145$ & $\mathrm{~N} f$ \\
\hline Gao $Y^{[39]}$ & 2014 & $\mathrm{RC}$ & 6 & 69.1 & NA & 39.1 & ETV+HBIG & 57.1 & $\begin{array}{l}\text { reappearance } \\
\text { of both } \\
\text { HBsAg and } \\
\text { HBV DNA }\end{array}$ & $0 / 84$ & $\mathrm{~N} f$ \\
\hline $\begin{array}{l}\text { Fernández } \\
\text { [40] }\end{array}$ & 2015 & PC & 5 & 26.0 & 17.0 & 38.0 & $\begin{array}{l}\text { Sequential ETV, } \\
\text { TDF following } \\
\text { HBIG+ETV or } \\
\text { HBIG+TDF }\end{array}$ & 28 & $\begin{array}{l}\text { reappearance } \\
\text { of HBsAg } \\
\text { and/or HBV } \\
\text { DNA }\end{array}$ & $0 / 58$ & $0 /$ \\
\hline $\begin{array}{l}\text { Choudhary } \\
\text { NS }^{[41]}\end{array}$ & 2015 & PC & 5 & 76.0 & 0 & 22.7 & $\begin{array}{l}\text { Sequential ETV, } \\
\text { TDF following } \\
\text { HBIG+ETV or } \\
\text { HBIG+TDF }\end{array}$ & 43 & $\begin{array}{l}\text { reappearance } \\
\text { of HBsAg } \\
\text { and/or HBV } \\
\text { DNA }\end{array}$ & $1 / 175$ & $\mathrm{~N} f$ \\
\hline Shen $S^{[42]}$ & 2015 & $\mathrm{RC}$ & 5 & 34.2 & NA & 46.4 & ETV + HBIG & 45.8 & $\begin{array}{l}\text { reappearance } \\
\text { of HBsAg or } \\
\text { HBV DNA }\end{array}$ & $5 / 491$ & $\mathrm{~N} f$ \\
\hline Chen $\mathrm{G}^{[43]}$ & 2015 & PC & 6 & NA & NA & 21.5 & ETV+HBIG & 36 & $\begin{array}{l}\text { reappearance } \\
\text { of both } \\
\text { HBsAg and } \\
\text { HBV DNA }\end{array}$ & $5 / 102$ & $\mathrm{~N} f$ \\
\hline $\begin{array}{l}\text { Idilman } \\
\mathrm{R}^{[44]}\end{array}$ & 2016 & PC & 6 & 29.0 & 29.2 & 41.9 & $\begin{array}{l}\text { ETV+HBIG, } \\
\text { TDF+HBIG }\end{array}$ & 46 & $\begin{array}{l}\text { reappearance } \\
\text { of HBsAg }\end{array}$ & $1 / 89$ & $\mathrm{~N} f$ \\
\hline $\begin{array}{l}\text { Togashi } \\
\mathrm{J}^{[45]}\end{array}$ & 2016 & $\mathrm{RC}$ & 4 & 30.0 & NA & NA & $\mathrm{ETV}+\mathrm{HBIG}$ & 64 & $\begin{array}{l}\text { reappearance } \\
\text { of HBsAg or } \\
\text { HBV DNA }\end{array}$ & $0 / 12$ & $\mathrm{~N} f$ \\
\hline Nolan $A^{[46]}$ & 2016 & $\mathrm{RC}$ & 4 & 51.7 & NA & NA & $\begin{array}{l}\text { Sequential ETV, } \\
\text { TDF following } \\
\text { HBIG+ETV or } \\
\text { HBIG+TDF }\end{array}$ & 28 & NA & $0 / 17$ & $0 /$ \\
\hline
\end{tabular}




\begin{tabular}{|c|c|c|c|c|c|c|c|c|c|c|c|}
\hline Fung $\mathrm{J}^{[47]}$ & 2017 & PC & 5 & 61.0 & NA & 36.6 & ETV & 59 & $\begin{array}{l}\text { reappearance } \\
\text { of HBsAg or } \\
\text { HBV DNA }\end{array}$ & $14 / 242$ & 9/: \\
\hline Gane $E^{[48]}$ & 2018 & $\mathrm{RCT}$ & $\begin{array}{l}\text { Unclear } \\
\text { risk of } \\
\text { bias }\end{array}$ & NA & NA & NA & $\begin{array}{l}\text { TDF, sequential } \\
\text { TAF following } \\
\text { TDF }\end{array}$ & 12 & HBV viremia & $0 / 48$ & $\mathrm{~N} f$ \\
\hline Saab $S^{[49]}$ & 2019 & $\mathrm{RC}$ & 5 & 37.0 & NA & 80.0 & $\begin{array}{l}\text { Sequential TAF } \\
\text { following HBIG }\end{array}$ & 57.4 & $\begin{array}{l}\text { reappearance } \\
\text { of HBsAg }\end{array}$ & $0 / 32$ & $\mathrm{~N} f$ \\
\hline Lee $W C^{[50]}$ & 2019 & $\mathrm{RC}$ & 4 & NA & NA & 54.7 & $\begin{array}{l}\text { Sequential ETV } \\
\text { following } \\
\text { HBIG+ETV }\end{array}$ & 42.2 & $\begin{array}{l}\text { reappearance } \\
\text { of HBsAg }\end{array}$ & $8 / 80$ & $\mathrm{~N} f$ \\
\hline $\begin{array}{l}\text { Teegen } \\
\text { EM }^{[51]}\end{array}$ & 2019 & $\mathrm{RC}$ & 5 & NA & 12.2 & 20.5 & $\begin{array}{l}\text { ETV+HBIG, } \\
\text { TDF+HBIG }\end{array}$ & 166.8 & $\begin{array}{l}\text { reappearance } \\
\text { of HBsAg or } \\
\text { HBV DNA }\end{array}$ & $0 / 22$ & $\mathrm{~N} f$ \\
\hline $\begin{array}{l}\text { Darweesh } \\
\mathrm{SK}^{[52]}\end{array}$ & 2019 & $\mathrm{RC}$ & 6 & NA & NA & 13.6 & $\mathrm{ETV} \pm \mathrm{HBIG}$ & 72 & $\begin{array}{l}\text { reappearance } \\
\text { of both } \\
\text { HBsAg and } \\
\text { HBV DNA }\end{array}$ & $0 / 34$ & $\mathrm{~N} f$ \\
\hline $\begin{array}{l}\text { Muthiah } \\
\text { MD }^{[53]}\end{array}$ & 2020 & $\mathrm{RC}$ & 5 & 50.0 & NA & 62.0 & $\begin{array}{l}\text { ETV } \pm \text { HBIG, } \\
\text { TDF } \pm \mathrm{HBIG}\end{array}$ & 79 & HBV viremia & $2 / 38$ & $\mathrm{~N} f$ \\
\hline
\end{tabular}

PC: prospective cohort; RC: retrospective cohort; RCT: randomized controlled trial; HP NAs: high potent nucleot(s)ide analogues; ETV: entecavir; TDF: tenofovir disoproxil fumarate; TAF: tenofovir alafenamide; HBIG: hepatitis B immune globulin

No observational studies scored under 4 or above 6 , indicating all of them having fair quality. Both RCT had unclear risk of bias because the process of random sequence generation or blinding outcome assessment was not described.

\subsection{HBV recurrence rate}

The overall HBV recurrence rate was $0.92 \%\left(95 \% \mathrm{Cl} 0.47 \%-1.48 \%, \mathrm{I}^{2}=44 \%\right)$ (Figure 2$)$. HBV recurrence rate did not differ significantly between studies with and without detectable HBV DNA patients $(0.87 \%$ vs $0.00 \%, p=0.25)$, or studies with and without HDV superinfected patients $(1.00 \%$ vs $0.63 \%, p=0.69)($ Figure $S 1$, S2).

Subgroup analysis demonstrated the preventive effect of ETV-based, TDF-based and TAF-based therapies were comparable, and in this analysis episode of transient recurrence was counted as recurrence event ( $p=0.27$ ) (Figure S3). The frequency of HBV reactivation was inconsistent among patients receiving indefinite combination $(0.48 \%, 95 \% \mathrm{Cl} 0.10 \%-1.06 \%)$, NAs plus finite course of $\mathrm{HBIG}(1.05 \%, 95 \% \mathrm{Cl} 0.00 \%-4.38 \%)$ and $\mathrm{HP} \mathrm{NAs} \mathrm{alone}(5.00 \%, 95 \% \mathrm{Cl}$ $2.57 \%-8.07 \%)(p=0.001)$ (Figure 3). Further comparison suggested that the reactivation rate under indefinite combination was lower than that under HP NAs monotherapy $(p=0.0003)$ and similar to that under NAs plus finite course of HBIG $(p=0.53)$. For studies which enrolled viremia or HDV superinfected patients, HBV recurrence were comparable between indefinite and finite combination subgroups $(p=0.65, p=0.16)$ (Figure S4, S5). For patients received finite combination, the risk of reinfection didn't change significantly regardless of combination period (i.e. $\leq 6 \mathrm{~m}$ vs $>6 \mathrm{~m})(p=0.31)$ or the administration route of HBIG (i.e. IM vs change from IV to IM) $(p=0.26)$. There was no difference between studies under finite combination and monoprophylaxis ( $p=0.101)$.

\subsection{All-cause mortality and HBV-recurrence related mortality}

Patient survival was reported in 16 studies, and the pooled death rate was $7.29 \%\left(95 \% \mathrm{Cl} 4.42 \%-10.71 \%, \mathrm{I}^{2}=73 \%\right)$ (Figure S6). Based on detailed information of death from 8 studies, HBV-recurrence related death was $0.17 \%\left(95 \% \mathrm{Cl} 0.00 \%-1.51 \%, \mathrm{I}^{2}=37 \%\right.$ ) (Figure 4 ).

\subsection{HCC recurrence rate}

19 studies included patients with pre-transplant $\mathrm{HCC}$, and 5 reported information relevant to HCC recurrence. The aggregated HCC recurrence rate was $5.34 \%$ $\left(95 \% \mathrm{Cl} 0.78 \%-12.48 \%, \mathrm{I}^{2}=52 \%\right)$ (Figure 5).

\subsection{Renal function}

10 trials measured renal function, among which 3 observed significant eGFR/creatinine clearance deterioration (1 TDF based, 2 ETV based) ${ }^{30,33,47}$. Another 2 studies demonstrated a trend toward improved eGFR/CKD stage under sequential TAF treatment following TDF or HBIG+NAs ${ }^{48,49}$. The renal function remained at a stable level in other trials $35,36,40,41,52$.

\subsection{Sensitivity analysis}


After ruling out the abstracts and studies with follow-up period less than 24 months, the aggregated $\mathrm{HBV}$ recurrence was $1.37 \%$ ( $95 \% \mathrm{Cl} 0.46-2.60 \%)$. A proportion of original studies defined HBV recurrence by reappearance of HBsAg, and others defined by detectable HBV DNA. We compared the HBV recurrence under abovementioned two standards (i.e. HBsAg (or HBV DNA) vs HBV DNA (and HBsAg)) and found no significant difference between them $(p=0.49)$.

\section{Discussion}

Our meta-analysis demonstrated minimal risk of HBV reactivation under HP NAs-based regimens for LT recipients (0.92\%). In subgroup analysis the risk of reactivation was similar between studies with and without HBV viremia/HDV coinfected patients, suggesting that these elements might no longer affect the prophylaxis significantly in the era of HP NAs ${ }^{54,55}$. The recurrent $\mathrm{HCC}$ remained an alarming signal. Its association with HBV reactivation was revealed by Idilman R, Lee WC et al who confirmed $21.4 \%$ to $100 \%$ cases of recurrence detected with concomitant HCC recurrence ${ }^{32,39,44,50}$. For HP NAs, the recurrent HCC was supposed to present following challenges: HBV within tumor cells might be relatively inaccessible to drug because of the change in liver structure and blood supply. Beside the non-HCC tissues, closed circular DNA (ccc DNA) of HBV also existed in extrahepatic HCC micro-metastases and HCC cells, acting as potential reservoirs which couldn't be targeted by NAs. Furthermore, dysfunction of hepatic immune network induced by HCC might predispose to poorer response to antiviral treatment ${ }^{56-58}$. Although HCC was one of the major indications for LT, we found the HCC recurrence rate was not high (5.34\%). Identifying the small population with high risk of HCC recurrence might help to further decrease HCC and HBV recurrence. All-cause mortality in our study was low, comparing previous studies which applied HBIG or LP NAs-based prophylaxis ${ }^{59,60}$. Moreover, the HBV-flare related mortality was much lower than all-cause mortality. These results suggested effective antiviral prophylaxis have improved long-term clinical outcome for LT recipients notably.

In terms of the preventive strategy, whether HBIG is a necessity in the era of HP NAs remains controversial. Although HBIG has been the mainstay of prophylactic regimen, many investigators have been trying to reduce the usage of HBIG to overcome the disadvantages such as high cost and inconvenient administration. Although the preliminary research of lamivudine monoprophylaxis demonstrated $90 \%$ of prevention by week $24{ }^{61}$, later studies with longer follow-up resulted much lower effect (59\%-80\%) mainly because of drug resistance ${ }^{62-64}$. HP NAs (i.e. ETV, TDF, TAF) was an optimal choice for HBV prophylaxis due to superiority at efficacy and genetic barrier (65-68). Currently there were only two studies adopting HP NAs monoprophylaxis to over 10 patients 47,53 . These two studies both conducted long term follow-up (median follow-up period: $79 \mathrm{~m}$ and $59 \mathrm{~m}$ ), while the HBV recurrence rate in Fung J's cohort (5.8\%) was as twice as that in Muthiah MD's cohort (2.9\%). One of the reasons for the disparity could be the HBV DNA level. In Fung J's trial, $26 \%$ of the patients had HBV DNA more than $4 \mathrm{log} \mathrm{IU} / \mathrm{ml}$ at the time of transplant. And in Muthiah MD's cohort there were only $3 \%$ with more than 5 log copies/ml of HBV DNA. Subgroup analysis showed significant difference between HP NAs + HBIG and HP NAs monotherapy. These results suggested caution with HP NAs monoprophylaxis, especially for patients with high level of HBV DNA at the time of LT. On the other hand, similar HBV reactivation was observed between lifelong dual therapy $(n=1607)$ and HBIG withdrawal $(n=405)$. We noticed this finding was different from that at Cholongitas E's systematic review, in which indefinite combination of HP NAs and HBIG $(n=303)$, but not finite combination $(n=102)$, presented superior prevention to LAM plus HBIG 22. The inconsistence was reasonable considering Cholongitas E's study was publicized 7 years ago when there were fewer evidence for HP NAs-based therapies. There is no consensus at the timing to stop HBIG, and we didn't find significant difference between early and late withdrawal (i.e. $\leq 6 \mathrm{~m}$ vs $>6 \mathrm{~m}$ ). In this regard, individualized decision should be made based on kinetics of anti-HBs ${ }^{40,44,69}$. We did not conduct stratification by dosage because most of the studies applied low-dose of HBIG ( $\leq 1000 \mathrm{IU})$ one week/month post-LT.

Renal dysfunction is a major post-transplant morbidity, which negatively impacts the graft and patient survival ${ }^{70}$. The prevalence of renal failure in LT recipients was the second highest among non-renal solid organ transplant patients, the 5 -year cumulative incidence was $18-22 \%{ }^{70,71}$. Among the trials included in our analysis, there were 3 TDF/ETV-based studies reported deterioration in eGFR or creatinine clearance. It was difficult to conclude the impact of HP NAs on renal function in this meta-analysis since we could not rule out other important factors such as calcineurin inhibitors and surgery operation. While HP NAs with good renal safety profile are preferred since most of the patients require lifelong treatment. Minimal rates of renal function decline had been reported during long-term therapy with ETV and TDF in patients with CHB, while the nephrotoxic potential was higher for TDF 20,72-74. There had been several cases about TDF-associated Fanconi syndrome, including one LT recipient ${ }^{75-77}$. This issue might be mitigated by TAF, which has demonstrated a trend of improved renal function in CHB patients who were previously exposed to TDF ${ }^{78,79}$. In Gane E and Sabb S' studies, we saw the same trend of TAF in LT recipients 48,49

Our study has several strengths. To our knowledge this is the first meta-analysis for HP NAs-based prophylaxis in post-LT recipients. Comprehensive subgroup analysis was applied to examine different treatment strategies. However, the strengths of this meta-analysis should be weighed against some limitations. First, there were limited evidence of certain regimens (e.g. TAF-based regimen, HP NAs monoprophylaxis). Second, there were only two RCT included in our analysis, and most of the original studies were observational with medium quality. Third, heterogeneity was moderate across studies which might attribute to varied sample size and preventive therapeutics. All of these issues may affect the robustness of the data and limit interpretation of the results.

\section{Conclusions}

our systematic and meta-analysis suggested HP NAs-based regimens are highly effective at preventing HBV recurrence, and beneficial to long-term outcome for LT recipients. HBV recurrence prophylaxis was not affected by viremia or HDV coinfection. In terms of HP NAs options, ETV-based, TAF-based and TDFbased therapies demonstrated equivalent efficacy. HP NAS plus short-term HBIG serves an alternative to indefinite combination, and monotherapy of HP NAs might be appropriate for patients with low HBV DNA level before LT. To reduce risk of renal impairment, HP NAs with an optimized renal safety profile is preferred.

\section{List Of Abbreviations}


HBV, hepatitis B virus; LT, liver transplantation; HCC, hepatocecullar carcinoma; HBsAg, hepatitis B surface antigen; HBeAg hepatitis B e-antigen; HBIG, hepatitis B immunoglobulin; HP NAs, high potent nucleos(t)ide analogues; ETV: entecavir; TDF: tenofovir disoproxil fumarate; TAF: tenofovir alafenamide; LP NAs, low potent nucleos(t)ide analogues; LAM: lamivudine; LdT: telbivudine; ADV: adefovir; PC: prospective cohort; RC: retrospective cohort; RCT: randomized controlled trial; OR, odds ratio; $\mathrm{Cl}$, confidence interval; IM, intramuscular; IV, intravenous.

\section{Declarations}

\section{Ethics approval and consent to participate}

Not applicable

\section{Consent for publication}

Not applicable.

\section{Availability of data and material}

The datasets supporting the conclusions of this article is included within the article and its additional files.

\section{Competing interests}

MSL works for Gilead while concurrently enrolled in Ph.D.

\section{Funding}

This study was not supported by any commercial company or grants.

\section{Authors' contributions}

Deming Tan and Qian Lin designed the study and take responsibility for the entire process; Mingshu Li and Zhouhua Hou conducted literature search, data extraction and quality assessment; Guozhu Yao analyzed the data; Mingshu Li drafted the manuscript; All authors have read and approved the final paper.

\section{Acknowledgements}

The authors thank Ros Jia for providing statistical consult for this manuscript.

\section{References}

1. O'Grady JG, Smith HM, Davies SE, Daniels HM, Donaldson PT, Tan KC, et al. Hepatitis B virus reinfection after orthotopic liver transplantation. Serological and clinical implications. J Hepatol. 1992;14(1):104-11.

2. Terrault N, Roche B, Samuel D. Management of the hepatitis B virus in the liver transplantation setting: a European and an American perspective. Liver Transpl. 2005;11(7):716-32.

3. Fung J. Management of chronic hepatitis B before and after liver transplantation. World J Hepatol. 2015;7(10):1421-6.

4. Samuel D, Bismuth A, Mathieu D, Arulnaden JL, Reynes M, Benhamou JP, et al. Passive immunoprophylaxis after liver transplantation in HBsAg-positive patients. Lancet. 1991;337(8745):813-5.

5. Samuel D, Muller R, Alexander G, Fassati L, Ducot B, Benhamou JP, et al. Liver transplantation in European patients with the hepatitis B surface antigen. N Engl J Med. 1993;329(25):1842-7.

6. Santantonio T, Gunther S, Sterneck M, Rendina M, Messner M, Launois B, et al. Liver graft infection by HBV S-gene mutants in transplant patients receiving long-term HBIg prophylaxis. Hepatogastroenterology. 1999;46(27):1848-54.

7. Terrault NA, Zhou S, McCory RW, Pruett TL, Lake JR, Roberts JP, et al. Incidence and clinical consequences of surface and polymerase gene mutations in liver transplant recipients on hepatitis B immunoglobulin. Hepatology. 1998;28(2):555-61.

8. McMahon G, Ehrlich PH, Moustafa ZA, McCarthy LA, Dottavio D, Tolpin MD, et al. Genetic alterations in the gene encoding the major HBsAg: DNA and immunological analysis of recurrent HBsAg derived from monoclonal antibody-treated liver transplant patients. Hepatology. 1992;15(5):757-66.

9. Laryea MA, Watt KD. Immunoprophylaxis against and prevention of recurrent viral hepatitis after liver transplantation. Liver Transpl. 2012;18(5):514-23.

10. Gane EJ, Angus PW, Strasser S, Crawford DH, Ring J, Jeffrey GP, et al. Lamivudine plus low-dose hepatitis B immunoglobulin to prevent recurrent hepatitis B following liver transplantation. Gastroenterology. 2007;132(3):931-7.

11. Loomba R, Rowley AK, Wesley R, Smith KG, Liang TJ, Pucino F, et al. Hepatitis B immunoglobulin and Lamivudine improve hepatitis B-related outcomes after liver transplantation: meta-analysis. Clin Gastroenterol Hepatol. 2008;6(6):696-700.

12. Katz LH, Paul M, Guy DG, Tur-Kaspa R. Prevention of recurrent hepatitis B virus infection after liver transplantation: hepatitis B immunoglobulin, antiviral drugs, or both? Systematic review and meta-analysis. Transpl Infect Dis. 2010;12(4):292-308.

13. Seehofer D, Rayes N, Steinmuller T, Muller AR, Jonas S, Settmacher U, et al. Combination prophylaxis with Hepatitis B immunoglobulin and lamivudine after liver transplantation minimizes HBV recurrence rates unless evolution of pretransplant lamivudine resistance. Z Gastroenterol. 2002;40(9):795-9.

14. Zoulim F. A preliminary benefit-risk assessment of lamivudine for the treatment of chronic hepatitis B virus infection. Drug Saf. 2002;25(7):497-510. 
15. Wong GL, Seto WK, Wong VW, Yuen MF, Chan HL. Review article: long-term safety of oral anti-viral treatment for chronic hepatitis B. Aliment Pharmacol Ther. 2018;47(6):730-7.

16. Hadziyannis SJ, Tassopoulos NC, Heathcote EJ, Chang TT, Kitis G, Rizzetto M, et al. Long-term therapy with adefovir dipivoxil for HBeAg-negative chronic hepatitis B. N Engl J Med. 2005;352(26):2673-81.

17. Heathcote EJ, Marcellin P, Buti M, Gane E, De Man RA, Krastev Z, et al. Three-year efficacy and safety of tenofovir disoproxil fumarate treatment for chronic hepatitis B. Gastroenterology. 2011;140(1):132-43.

18. Kim YM, Shin HP, Lee JI, Joo KR, Cha JM, Jeon JW, et al. Real-world single-center experience with entecavir and tenofovir disoproxil fumarate in treatmentnaive and experienced patients with chronic hepatitis B. Saudi J Gastroenterol. 2018;24(6):326-35.

19. Sarin SK, Kumar M, Lau GK, Abbas Z, Chan HL, Chen CJ, et al. Asian-Pacific clinical practice guidelines on the management of hepatitis B: a 2015 update. Hepatol Int. 2016;10(1):1-98.

20. Idilman R. Management of special patient groups with hepatitis B virus infection: The EASL 2017 Clinical Practice Guidelines. Turk J Gastroenterol. 2017;28(6):518-21.

21. Terrault NA, Lok ASF, McMahon BJ, Chang KM, Hwang JP, Jonas MM, et al. Update on Prevention, Diagnosis, and Treatment of Chronic Hepatitis B: AASLD 2018 Hepatitis B Guidance. Clin Liver Dis (Hoboken). 2018;12(1):33-4.

22. Cholongitas E, Papatheodoridis GV. High genetic barrier nucleos(t)ide analogue(s) for prophylaxis from hepatitis $B$ virus recurrence after liver transplantation: a systematic review. Am J Transplant. 2013;13(2):353-62.

23. Moher D, Liberati A, Tetzlaff J, Altman DG, Group P. Preferred reporting items for systematic reviews and meta-analyses: the PRISMA statement. PLoS Med. 2009;6(7):e1000097.

24. Wells. G, Shea. B, O'Connell. D, Peterson. J, Welch. V. The Newcastle-Ottawa Scale (NOS) for assessing the quality of nonrandomised studies in metaanalyses.

25. Higgins JP, Altman DG, Gotzsche PC, Juni P, Moher D, Oxman AD, et al. The Cochrane Collaboration's tool for assessing risk of bias in randomised trials. BMJ. 2011;343:d5928.

26. Ryan. R. Heterogeneity and subgroup analyses in Cochrane Consumers and Communication Review Group reviews: Planning the analysis at protocol stage. 2014.

27. Petitti DB. Approaches to heterogeneity in meta-analysis. Stat Med. 2001;20(23):3625-33.

28. Xi ZF, Xia Q, Zhang JJ, Chen XS, Han LZ, Wang X, et al. The role of entecavir in preventing hepatitis B recurrence after liver transplantation. J Dig Dis. 2009;10(4):321-7.

29. Cai CJ, Lu MQ, Chen YH, Zhao H, Li MR, Chen GH. Clinical study on prevention of HBV re-infection by entecavir after liver transplantation. Clin Transplant. 2012;26(2):208-15.

30. Teperman LW, Poordad F, Bzowej N, Martin P, Pungpapong S, Schiano T, et al. Randomized trial of emtricitabine/tenofovir disoproxil fumarate after hepatitis B immunoglobulin withdrawal after liver transplantation. Liver Transpl. 2013;19(6):594-601.

31. Yi NJ, Choi JY, Suh KS, Cho JY, Baik M, Hong G, et al. Post-transplantation sequential entecavir monotherapy following 1-year combination therapy with hepatitis B immunoglobulin. J Gastroenterol. 2013;48(12):1401-10.

32. Kim YK, Kim SH, Lee SD, Park SJ. Clinical outcomes and risk factors of hepatitis B virus recurrence in patients who received prophylaxis with entecavir and hepatitis B immunoglobulin following liver transplantation. Transplant Proc. 2013;45(8):3052-6.

33. Perrillo R, Buti M, Durand F, Charlton M, Gadano A, Cantisani G, et al. Entecavir and hepatitis B immune globulin in patients undergoing liver transplantation for chronic hepatitis B. Liver Transpl. 2013;19(8):887-95.

34. Ueda Y, Marusawa H, Kaido T, Ogura Y, Ogawa K, Yoshizawa A, et al. Efficacy and safety of prophylaxis with entecavir and hepatitis B immunoglobulin in preventing hepatitis B recurrence after living-donor liver transplantation. Hepatol Res. 2013;43(1):67-71.

35. Elsiesy H, Abaalkhail F, Hashim A, Atallah K, Al Sebayel M, Al Hamoudi W. Hepatitis B prophylaxis post liver transplantation with tenofovir or entercavir [abstract]. Journal of Hepatology. 2013.

36. Cholongitas E, Goulis I, Antoniadis N, Fouzas I, Imvrios G, Papanikolaou V, et al. New nucleos(t)ide analogue monoprophylaxis after cessation of hepatitis B immunoglobulin is effective against hepatitis B recurrence. Transpl Int. 2014;27(10):1022-8.

37. Na GH, Kim DG, Han JH, Kim EY, Lee SH, Hong TH, et al. Prevention and risk factors of hepatitis B recurrence after living donor liver transplantation. J Gastroenterol Hepatol. 2014;29(1):151-6.

38. Hu. T, Chen. C, Lin. C, Wang. C, Chiu. K, Yong. C. Combination of entecavir plus low-dose on-demand hepatitis B immunoglobulin is effective with very low hepatitis B recurrence after liver transplantation [abstract]. Transplantation. 2014;97 Suppl 8:S53-9.

39. Gao YJ, Zhang M, Jin B, Meng FP, Ma XM, Liu ZW, et al. Clinical-pathological analysis of hepatitis B virus recurrence after liver transplantation in Chinese patients. J Gastroenterol Hepatol. 2014;29(3):554-60.

40. Fernandez I, Loinaz C, Hernandez O, Abradelo M, Manrique A, Calvo J, et al. Tenofovir/entecavir monotherapy after hepatitis B immunoglobulin withdrawal is safe and effective in the prevention of hepatitis B in liver transplant recipients. Transpl Infect Dis. 2015;17(5):695-701.

41. Choudhary NS, Saraf N, Saigal S, Mohanka R, Rastogi A, Goja S, et al. Low-dose short-term hepatitis B immunoglobulin with high genetic barrier antivirals: the ideal post-transplant hepatitis B virus prophylaxis? Transpl Infect Dis. 2015;17(3):329-33.

42. Shen S, Jiang L, Xiao GQ, Yan LN, Yang JY, Wen TF, et al. Prophylaxis against hepatitis B virus recurrence after liver transplantation: a registry study. World J Gastroenterol. 2015;21(2):584-92. 
43. Chen G, Liu H, Hu ZQ, Bai JH, Liu QY, Zhao YP, et al. A new scheme with infusion of hepatitis B immunoglobulin combined with entecavir for prophylaxis of hepatitis B virus recurrence among liver transplant recipients. Eur J Gastroenterol Hepatol. 2015;27(8):901-6.

44. Idilman R, Akyildiz M, Keskin O, Gungor G, Yilmaz TU, Kalkan C, et al. The long-term efficacy of combining nucleos(t)ide analog and low-dose hepatitis B immunoglobulin on post-transplant hepatitis B virus recurrence. Clin Transplant. 2016;30(10):1216-21.

45. Togashi. J, Akamatsu. N, Sugawara. Y, Tamura. S, Kaneko. J. Long-term outcomes of prophylaxis with entecavir and hepatitis B immunoglobulin after liver transplantation for hepatitis B virus.[abstract]. Transplantation. 2016;100 (5 Supplement 1) (p S181).

46. Nolan. A, Onwudiwe. C, Rangnekar. A, Satoskar. R, Fishbein. T. Hepatitis B immune globulin withdrawal in HBsAg positive liver transplant patients [abstract]

Am J Transplant. 2016;16 (suppl 3).

47. Fung J, Wong T, Chok K, Chan A, Cheung TT, Dai JW, et al. Long-term outcomes of entecavir monotherapy for chronic hepatitis B after liver transplantation: Results up to 8 years. Hepatology. 2017;66(4):1036-44.

48. Gane E, George B, Munn S, Wang H, Suri V, Flaherty JF, et al. Evaluation of renal and bone safety in post liver transplant patients with chronic kidney disease receiving Tenofovir Alafenamide for HBV prophylaxis [abstract]. Journal of Hepatology. 2018;68.

49. Saab S, Song D, Challita YP, Xiwen Zhou T, Saab EG, Viramontes MR, et al. Long-term outcomes with oral therapy in liver transplant recipients with hepatitis B. Clin Transplant. 2019;33(12):e13740.

50. Lee WC, Chou HS, Wu TH, Cheng CH, Lee CF, Wang YC, et al. Low-dose anti-hepatitis B immunoglobulin regimen as prophylaxis for hepatitis B recurrence after liver transplantation. Transpl Infect Dis. 2019;21(6):e13190.

51. Teegen EM, Maurer MM, Globke B, Pratschke J, Eurich D. Liver transplantation for Hepatitis-B-associated liver disease - Three decades of experience. Transpl Infect Dis. 2019;21(1):e12997.

52. Darweesh SK, Gad AA, Akroof K, ElLatif ZA. Entecavir and other nucleos(t)ide analogs prophylaxis in hepatitis B virus-related liver transplantation: longterm efficacy and safety. Eur J Gastroenterol Hepatol. 2019;31(5):607-12.

53. Muthiah MD, Tan EY, Chua SHM, Huang DQY, Bonney GK, Kow AWC, et al. Nucleoside analog monotherapy for prophylaxis in Hepatitis B liver transplant patients is safe and efficacious. Hepatol Int. 2020;14(1):57-69.

54. Zhang BC, Chen H, Wang X, Fan TY, Li J, Zhang Q, et al. Risk factors for hepatitis B recurrence after liver transplantation for HBV-related liver disease. Zhonghua Gan Zang Bing Za Zhi. 2016;24(7):481-5.

55. Marzano A, Gaia S, Ghisetti V, Carenzi S, Premoli A, Debernardi-Venon W, et al. Viral load at the time of liver transplantation and risk of hepatitis B virus recurrence. Liver Transpl. 2005;11(4):402-9.

56. Faria LC, Gigou M, Roque-Afonso AM, Sebagh M, Roche B, Fallot G, et al. Hepatocellular carcinoma is associated with an increased risk of hepatitis B virus recurrence after liver transplantation. Gastroenterology. 2008;134(7):1890-9; quiz 2155.

57. Su TH, Kao JH. Unmet Needs in Clinical and Basic Hepatitis B Virus Research. J Infect Dis. 2017;216(suppl_8):S750-S6.

58. Pineiro Fernandez J, Luddy KA, Harmon C, O'Farrelly C. Hepatic Tumor Microenvironments and Effects on NK Cell Phenotype and Function. Int J Mol Sci. 2019;20(17).

59. Burra P, Germani G, Adam R, Karam V, Marzano A, Lampertico P, et al. Liver transplantation for HBV-related cirrhosis in Europe: an ELTR study on evolution and outcomes. J Hepatol. 2013;58(2):287-96.

60. Hu Z, Zhou J, Wang H, Zhang M, Li S, Huang Y, et al. Survival in liver transplant recipients with hepatitis B- or hepatitis C-associated hepatocellular carcinoma: the Chinese experience from 1999 to 2010. PLoS One. 2013;8(4):e61620.

61. Grellier L, Mutimer D, Ahmed M, Brown D, Burroughs AK, Rolles K, et al. Lamivudine prophylaxis against reinfection in liver transplantation for hepatitis B cirrhosis. Lancet. 1996;348(9036):1212-5.

62. Perrillo RP, Wright T, Rakela J, Levy G, Schiff E, Gish R, et al. A multicenter United States-Canadian trial to assess lamivudine monotherapy before and after liver transplantation for chronic hepatitis B. Hepatology. 2001;33(2):424-32.

63. Zheng S, Chen Y, Liang T, Lu A, Wang W, Shen Y, et al. Prevention of hepatitis B recurrence after liver transplantation using lamivudine or lamivudine combined with hepatitis B Immunoglobulin prophylaxis. Liver Transpl. 2006;12(2):253-8.

64. Fung J, Chan SC, Cheung C, Yuen MF, Chok KS, Sharr W, et al. Oral nucleoside/nucleotide analogs without hepatitis B immune globulin after liver transplantation for hepatitis B. Am J Gastroenterol. 2013;108(6):942-8.

65. Chang TT, Chao YC, Gorbakov VV, Han KH, Gish RG, de Man R, et al. Results of up to 2 years of entecavir vs lamivudine therapy in nucleoside-naive HBeAg-positive patients with chronic hepatitis B. J Viral Hepat. 2009;16(11):784-9.

66. Chang TT, Gish RG, de Man R, Gadano A, Sollano J, Chao YC, et al. A comparison of entecavir and lamivudine for HBeAg-positive chronic hepatitis B. N Engl J Med. 2006;354(10):1001-10.

67. Kitrinos KM, Corsa A, Liu Y, Flaherty J, Snow-Lampart A, Marcellin P, et al. No detectable resistance to tenofovir disoproxil fumarate after 6 years of therapy in patients with chronic hepatitis B. Hepatology. 2014;59(2):434-42.

68. Cathcart AL, Chan HL, Bhardwaj N, Liu Y, Marcellin P, Pan CQ, et al. No Resistance to Tenofovir Alafenamide Detected through 96 Weeks of Treatment in Patients with Chronic Hepatitis B Infection. Antimicrob Agents Chemother. 2018;62(10).

69. Roche. B, Roque-Afonso. A, Nevens. F, Samuel. D. Rational Basis for Optimizing Short and Long-term Hepatitis B Virus Prophylaxis Post Liver Transplantation: Role of Hepatitis B Immune Globulin. Transplantation. 2015;99(7):1321-34. 
70. Sharma P, Bari K. Chronic Kidney Disease and Related Long-Term Complications After Liver Transplantation. Adv Chronic Kidney Dis. 2015;22(5):404-11.

71. Kida Y. Chronic renal failure after transplantation of a nonrenal organ. N Engl J Med. 2003;349(26):2563-5; author reply -5.

72. Buti M, Tsai N, Petersen J, Flisiak R, Gurel S, Krastev Z, et al. Seven-year efficacy and safety of treatment with tenofovir disoproxil fumarate for chronic hepatitis B virus infection. Dig Dis Sci. 2015;60(5):1457-64.

73. Lampertico P, Chan HL, Janssen HL, Strasser SI, Schindler R, Berg T. Review article: long-term safety of nucleoside and nucleotide analogues in HBVmonoinfected patients. Aliment Pharmacol Ther. 2016;44(1):16-34.

74. Han Y, Zeng A, Liao H, Liu Y, Chen Y, Ding H. The efficacy and safety comparison between tenofovir and entecavir in treatment of chronic hepatitis B and HBV related cirrhosis: A systematic review and Meta-analysis. Int Immunopharmacol. 2017;42:168-75.

75. Samarkos M, Theofanis V, Eliadi I, Vlachogiannakos J, Polyzos A. Tenofovir-associated Fanconi syndrome in a patient with chronic hepatitis B. J Gastrointestin Liver Dis. 2014;23(3):342.

76. Llach J, Gomez-Hernando M, Colmenero J, Forns X. Fanconi syndrome due to tenofovir disoproxil fumarate (TDF) after liver transplantation. Dig Liver Dis. 2019;51(9):1352-3.

77. Conti F, Vitale G, Cursaro C, Bernardi M, Andreone P. Tenofovir-induced Fanconi syndrome in a patient with chronic hepatitis B monoinfection. Ann Hepatol. 2016;15(2):273-6.

78. Lampertico. P, Buti. M, Fung. S, Ahn. S, Chuang. W. Switching from tenofovir disoproxil fumarate to tenofovir alafenamide in virologically suppressed patients with chronic hepatitis B: a randomised, double-blind, phase 3, multicentre non-inferiority study. Lancet Gastroenterol Hepatol. 2020;9(10):114650 .

79. Agarwal K, Brunetto M, Seto WK, Lim YS, Fung S, Marcellin P, et al. 96weeks treatment of tenofovir alafenamide vs. tenofovir disoproxil fumarate for hepatitis B virus infection. J Hepatol. 2018;68(4):672-81.

\section{Figures}

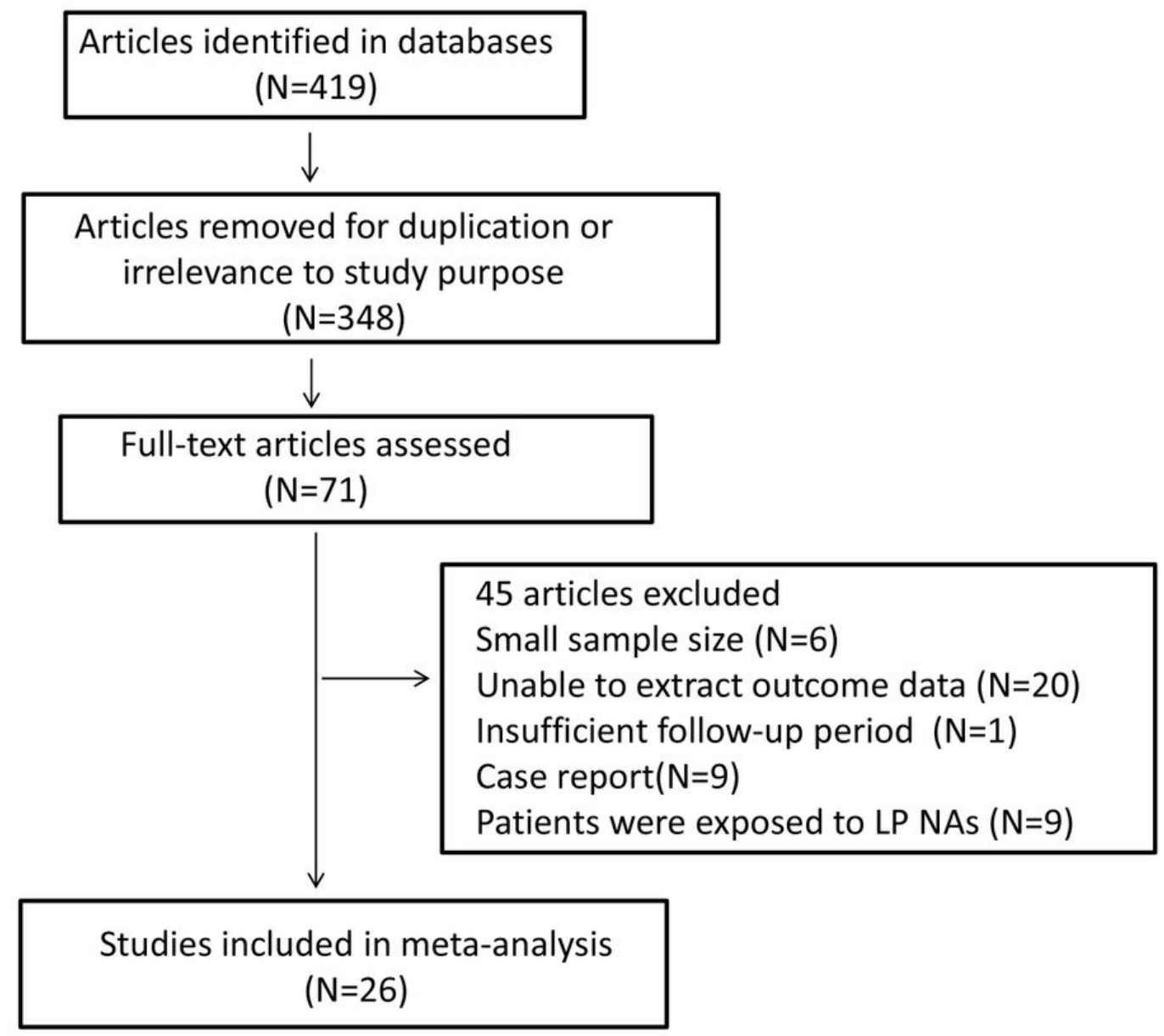

Figure 1

Flowchart of literature search and screen 
Study

Xi ZF

Cai CJ

Teperman LW

Yi NJ

Kim YK

Perrillo $R$

Ueda $Y$

Elsiesy $\mathrm{H}$

Cholongitas $\mathrm{E}$

$\mathrm{Na} \mathrm{GH}$

$\mathrm{Hu} \mathrm{TH}$

Gao $Y$

Fernández I

Choudhary NS

Shen S

Chen $\mathrm{G}$

Idilman R

Togashi J

Nolan A

Fung $J$

Gane E

Sabb S

Lee WC

Teegen EM

Darweesh SK

Muthiah MD

Fixed effect model

Random effects model

Heterogeneity: $I^{2}=44 \%, \tau^{2}=0.0022, p<$\begin{tabular}{ccccc|c|c}
0.01 & & & & & \\
0 & 0.05 & 0.1 & 0.15 & 0.2 & 0.25
\end{tabular}
Proportion

$95 \%-\mathrm{Cl}$

$0.0000[0.0000 ; 0.1157] \quad 1.3 \% \quad 2.3 \%$

$0.0000[0.0000 ; 0.0569] \quad 2.7 \% \quad 3.9 \%$

$0.0000[0.0000 ; 0.0949] \quad 1.6 \% \quad 2.7 \%$

$0.0345[0.0009 ; 0.1776] \quad 1.2 \% \quad 2.2 \%$

$0.0325[0.0106 ; 0.0741] \quad 6.5 \% \quad 6.2 \%$

$0.0000[0.0000 ; 0.0587] \quad 2.6 \% \quad 3.8 \%$

$0.0000[0.0000 ; 0.1323] \quad 1.1 \% \quad 2.0 \%$

$0.0000[0.0000 ; 0.2180] \quad 0.6 \% \quad 1.3 \%$

$0.0000[0.0000 ; 0.1234] \quad 1.2 \% \quad 2.2 \%$

$0.0153[0.0042 ; 0.0386] \quad 11.0 \% \quad 7.5 \%$

$0.0138[0.0017 ; 0.0489] \quad 6.1 \% \quad 6.0 \%$

$0.0000[0.0000 ; 0.0430] \quad 3.5 \% \quad 4.6 \%$

$0.0000[0.0000 ; 0.0616] \quad 2.5 \% \quad 3.7 \%$

$0.0057[0.0001 ; 0.0314] \quad 7.4 \% \quad 6.5 \%$

$0.0102[0.0033 ; 0.0236] \quad 20.6 \% \quad 8.7 \%$

$0.0490[0.0161 ; 0.1107] \quad 4.3 \% \quad 5.1 \%$

$0.0112[0.0003 ; 0.0610] \quad 3.7 \% \quad 4.7 \%$

$0.0000[0.0000 ; 0.2646] \quad 0.5 \% \quad 1.1 \%$

$0.0000[0.0000 ; 0.1951] \quad 0.7 \% \quad 1.4 \%$

$0.0579[0.0320 ; 0.0952] \quad 10.2 \% \quad 7.3 \%$

$0.0000[0.0000 ; 0.0740] \quad 2.0 \% \quad 3.2 \%$

$0.0000[0.0000 ; 0.1089] \quad 1.4 \% \quad 2.4 \%$

$0.1000[0.0442 ; 0.1876] \quad 3.4 \% \quad 4.5 \%$

$0.0000[0.0000 ; 0.1544] \quad 0.9 \% \quad 1.8 \%$

$0.0000[0.0000 ; 0.1028] \quad 1.4 \% \quad 2.5 \%$

$0.0526[0.0064 ; 0.1775] \quad 1.6 \% \quad 2.7 \%$

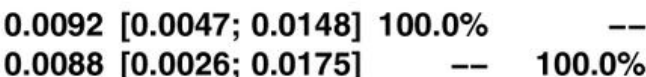

Figure 2

Forest plots showing the results of pooled HBV recurrence rate in LT recipients treated by HP NAs-based prophylaxis 


\begin{tabular}{|c|c|c|c|c|c|c|c|c|}
\hline Events & Total & & & & Proportion & $95 \%-\mathrm{Cl}$ & $\begin{array}{l}\text { Weight } \\
\text { (fixed) }\end{array}$ & $\begin{array}{r}\text { Weight } \\
\text { (random) }\end{array}$ \\
\hline \multicolumn{9}{|l|}{ byvar = Indefinite combination } \\
\hline $\begin{array}{ll}\text { Ramazan I } & 1\end{array}$ & $89+$ & & & & 0.0112 & {$[0.0003 ; 0.0610]$} & $3.9 \%$ & $5.0 \%$ \\
\hline Teperman LW & 19 & & & & 0.0000 & {$[0.0000 ; 0.1765]$} & $0.8 \%$ & $1.6 \%$ \\
\hline Xi ZF & 30 & & & & 0.0000 & {$[0.0000 ; 0.1157]$} & $1.3 \%$ & $2.4 \%$ \\
\hline Shen S & $491 \div$ & & & & 0.0102 & {$[0.0033 ; 0.0236]$} & $21.4 \%$ & $9.4 \%$ \\
\hline $\mathrm{Na} \mathrm{GH}$ & $262 \div$ & & & & 0.0153 & {$[0.0042 ; 0.0386]$} & $11.4 \%$ & $8.0 \%$ \\
\hline Teegen EM & 22 & & & & 0.0000 & {$[0.0000 ; 0.1544]$} & $1.0 \%$ & $1.8 \%$ \\
\hline Togashi J & 12 & & & & 0.0000 & {$[0.0000 ; 0.2646]$} & $0.5 \%$ & $1.1 \%$ \\
\hline $\mathrm{Hu} \mathrm{TH}$ & $145 \div$ & & & & 0.0138 & {$[0.0017 ; 0.0489]$} & $6.3 \%$ & $6.4 \%$ \\
\hline Darweesh SK & 32 & & & & 0.0000 & [0.0000; 0.1089$]$ & $1.4 \%$ & $2.5 \%$ \\
\hline Chen $\mathrm{G}$ & 102 & + & & & 0.0490 & {$[0.0161 ; 0.1107]$} & $4.5 \%$ & $5.4 \%$ \\
\hline Gao Y & 84 & & & & 0.0000 & {$[0.0000 ; 0.0430]$} & $3.7 \%$ & $4.8 \%$ \\
\hline Kim YK & 154 & $\mp$ & & & 0.0325 & {$[0.0106 ; 0.0741]$} & $6.7 \%$ & $6.6 \%$ \\
\hline Perrillo R & 61 & & & & 0.0000 & {$[0.0000 ; 0.0587]$} & $2.7 \%$ & $4.0 \%$ \\
\hline Cai CJ & $63 \stackrel{4}{+1}$ & & & & 0.0000 & {$[0.0000 ; 0.0569]$} & $2.8 \%$ & $4.0 \%$ \\
\hline Ueda $Y$ & 26 & & & & 0.0000 & [0.0000; 0.1323$]$ & $1.2 \%$ & $2.1 \%$ \\
\hline Elsiesy H & 15 & & & & 0.0000 & {$[0.0000 ; 0.2180]$} & $0.7 \%$ & $1.3 \%$ \\
\hline Fixed effect model & $1607 \phi_{i}^{i}$ & & & & 0.0048 & {$[0.0010 ; 0.0106]$} & $70.2 \%$ & -- \\
\hline Random effects model & 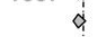 & & & & 0.0048 & {$[0.0010 ; 0.0106]$} & -- & $66.5 \%$ \\
\hline \multicolumn{9}{|l|}{ Heterogeneity: $I^{2}=0 \%, \tau^{2}=0, p=0.67$} \\
\hline \multicolumn{9}{|l|}{ byvar = finite combination } \\
\hline Fernández I & $58+$ & & & & 0.0000 & {$[0.0000 ; 0.0616]$} & $2.5 \%$ & $3.8 \%$ \\
\hline Teperman LW & 18 & & & & 0.0000 & {$[0.0000 ; 0.1853]$} & $0.8 \%$ & $1.6 \%$ \\
\hline Lee WC & 80 & & & & 0.1000 & {$[0.0442 ; 0.1876]$} & $3.5 \%$ & $4.7 \%$ \\
\hline Choudhary NS & $175 \div$ & & & & 0.0057 & {$[0.0001 ; 0.0314]$} & $7.6 \%$ & $6.9 \%$ \\
\hline Cholongitas E & 28 & & & & 0.0000 & {$[0.0000 ; 0.1234]$} & $1.2 \%$ & $2.2 \%$ \\
\hline Nolan A & 17 & & & & 0.0000 & {$[0.0000 ; 0.1951]$} & $0.8 \%$ & $1.5 \%$ \\
\hline YiNJ & 29 & & & & 0.0345 & {$[0.0009 ; 0.1776]$} & $1.3 \%$ & $2.3 \%$ \\
\hline Fixed effect model & 405 & & & & 0.0090 & {$[0.0004 ; 0.0245]$} & $17.7 \%$ & - \\
\hline Random effects model & & & & & 0.0105 & {$[0.0000 ; 0.0438]$} & - & $23.0 \%$ \\
\hline \multicolumn{9}{|c|}{ Heterogeneity: $I^{2}=62 \%, \tau^{2}=0.0079, p=0.62$} \\
\hline \multicolumn{9}{|l|}{ byvar = HP NUC monotherapy } \\
\hline Muthiah MD $\quad 1$ & 35 & & & & 0.0286 & {$[0.0007 ; 0.1492]$} & $1.5 \%$ & $2.7 \%$ \\
\hline Fung $\mathrm{J}$ & 242 & 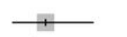 & & & 0.0579 & {$[0.0320 ; 0.0952]$} & $10.5 \%$ & $7.8 \%$ \\
\hline Fixed effect model & 277 & $\infty$ & & & 0.0500 & {$[0.0257 ; 0.0807]$} & $12.1 \%$ & -- \\
\hline \multicolumn{9}{|l|}{ Heterogeneity: $I^{2}=0 \%, \tau^{2}=0, p=0.62$} \\
\hline Fixed effect model & $2289 \diamond$ & & & & 0.0090 & {$[0.0043 ; 0.0147]$} & $100.0 \%$ & \\
\hline Random effects model & $\diamond$ & & & & 0.0088 & {$[0.0025 ; 0.0177]$} & - & $100.0 \%$ \\
\hline Heterogeneity: $I^{2}=42 \%, \tau^{2}=0.0021$ & $1, p=0 ! 02$ & 1 & 1 & 1 & & & & \\
\hline Residual heterogeneity: $I^{2}=22 \%, p$ & $=0.170$ & 0.05 & 0.15 & 0.25 & & & & \\
\hline
\end{tabular}

Figure 3

Forest plots showing the results of meta-analysis comparing HBV recurrence rate in studies under indefinite combination of HP NAs +HBIG, finite combination of HP NAs +HBIG and HP NAs monotherapy

\section{Study}

Teperman LW

Yi NJ

Kim YK

Ueda $Y$

Cholongitas $\mathrm{E}$

Fernández I

Nolan A

Fung $\mathrm{J}$

Fixed effect model

Random effects model
Events Total

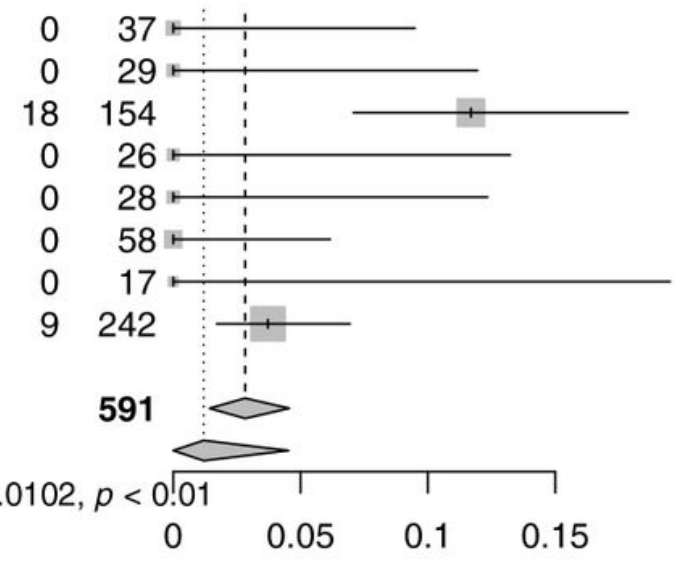

$0.05 \quad 0.1 \quad 0.15$

Proportion

$0.0000[0.0000 ; 0.0949]$

$0.0000[0.0000 ; 0.1194]$

$0.1169[0.0708 ; 0.1784]$

0.0000 [0.0000; 0.1323]

0.0000 [0.0000; 0.1234$]$

0.0000 [0.0000; 0.0616]

$0.0000[0.0000 ; 0.1951]$

$0.0372[0.0171 ; 0.0694]$

0.0282 [0.0143; 0.0455] $100.0 \%$ 0.0120 [0.0000; 0.0453 ]
Weight Weight

(fixed) (random)

$\begin{array}{rr}6.3 \% & 11.9 \% \\ 5.0 \% & 10.7 \% \\ 26.0 \% & 16.9 \% \\ 4.5 \% & 10.2 \% \\ 4.8 \% & 10.5 \% \\ 9.8 \% & 13.8 \% \\ 2.9 \% & 8.2 \% \\ 40.8 \% & 17.8 \% \\ 100.0 \% & -\overline{-} \\ -- & 100.0 \%\end{array}$

Heterogeneity: $I^{2}=72 \%, \tau^{2}=0.0102, p<0.01$

Figure 4

Forest plots showing the results of pooled HBV-recurrence related mortality in LT recipients treated by HP NAs-based prophylaxis 


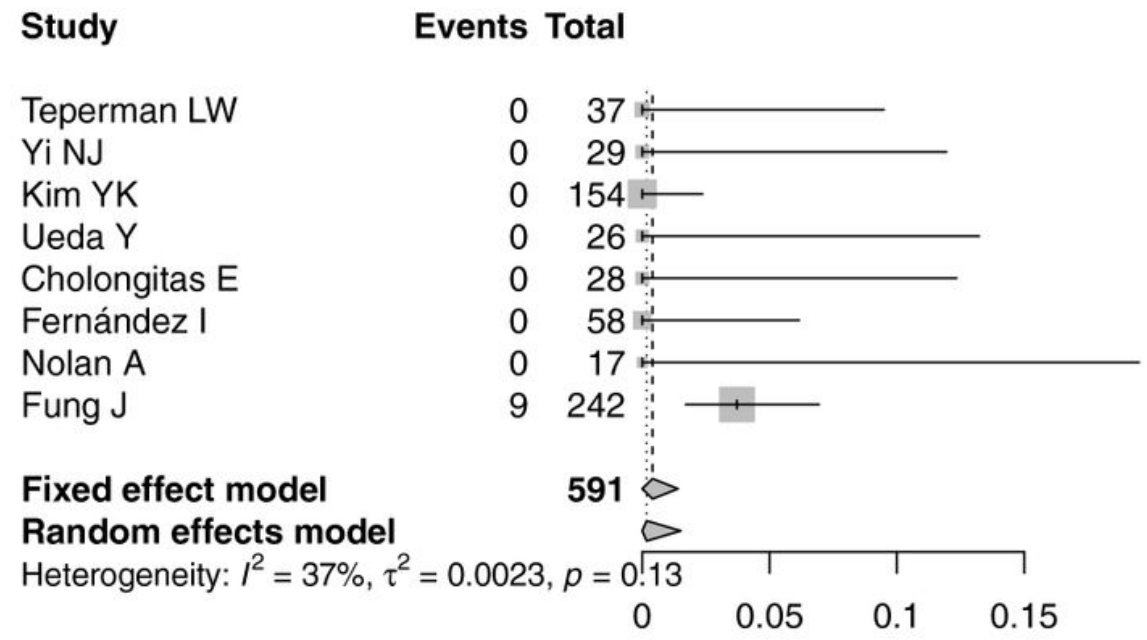

Proportion

$0.0000[0.0000 ; 0.0949]$

0.0000 [0.0000; 0.1194]

$0.0000[0.0000 ; 0.0237]$

0.0000 [0.0000; 0.1323]

0.0000 [0.0000; 0.1234]

0.0000 [0.0000; 0.0616$]$

0.0000 [0.0000; 0.1951$]$

$0.0372[0.0171 ; 0.0694]$

$0.0041[0.0000 ; 0.0140] 100.0 \%$

0.0017 [0.0000; 0.0151]
Weight Weight

(fixed) (random)

$6.3 \% \quad 9.7 \%$

$5.0 \% \quad 8.1 \%$

$26.0 \% \quad 22.2 \%$

$4.5 \% \quad 7.5 \%$

$4.8 \% \quad 7.9 \%$

$9.8 \% \quad 13.3 \%$

$2.9 \% \quad 5.3 \%$

$40.8 \% \quad 26.1 \%$

$100.0 \%$

Figure 5

Forest plots showing the results of pooled HCC recurrence rate in LT recipients treated by HP NAs-based regimens

\section{Supplementary Files}

This is a list of supplementary files associated with this preprint. Click to download.

- SupplementalFigure3.pdf

- Supplementalfigure1.pdf

- Supplementalfigure5.pdf

- Supplementalfigure2.pdf

- Supplementalfigure6.pdf

- Supplementalfigure4.pdf 